\title{
Evaluation of three tyne wheel hoe for reducing drudgery in vegetable crops
}

\section{P. Aparna and G. Prasad Babu}

See end of the Paper for authors' affiliation Author for Correspondence :

P. Aparna

Krishi Vigyan Kendra, Banavasi (A.P.) India
Received : 14.07.2018; Revised : 04.09.2018; Accepted : 20.09.2018

-ABSTRACT : Women constitute a major task force in agricultural operations in India. Therefore, it becomes necessary to study the ergonomics of women operators involved in weeding. Weeding is a main drudgery prone activity mostly performed by farm women and to resolve this problem Krishi Vigyan Kendra, Banavasi conducted front line demonstrations on the performance of improved weeder that is three tyne wheel hoe in reducing drudgery among women engaged in weeding activity in vegetable crops. Twenty farm women were selected randomly for the study. The results showed that the overall discomfort rate of hand hoe and three tyne wheel hoe was 8.1 and 4.7 (Table 4) i.e. more than moderate and light discomfort, respectively. Musculo-skeletal problems were decreased with improved weeding tool induced moderate to light discomfort/pain in shoulders, hands and arms compare to traditional method. Moderate drudgery index score of 53 per cent was recorded compare to traditional practice 72 per cent recorded as maximum. In the recommended weeding practice i.e. with three tyne wheel hoe, the same amount of work could be done in almost half of the time and work efficiency was increased by 93.3 per cent than normal weeding. Improved technologies for weeding activity for farm women is recommended so they can increase their efficiency, reduce the drudgery with time saving while performing weeding activity.

- KEY WORDS : Drudgery, Wheel hoe, Weeding

- HOW TO CITE THIS PAPER : Aparna, P. and Babu, G. Prasad (2018). Evaluation of three tyne wheel hoe for reducing drudgery in vegetable crops. Internat. J. Agric. Engg., 11(2) : 379-384, DOI: 10.15740/ HAS/IJAE/11.2/379-384. Copyright@ 2018: Hind Agri-Horticultural Society. 